\title{
PENGEMBANGAN APLIKASI GAME BERBASIS ANDROID SEBAGAI MEDIA PEMBELAJARAN PADA MATERI ARITMATIKA SOSIAL
}

\author{
Anis Mahiroh \\ Pendidikan Matematika, FMIPA, Universitas Negeri Surabaya, e-mail: anismahiroh@mhs.unesa.ac.id. \\ Atik Wintarti \\ Pendidikan Matematika, FMIPA, Universitas Negeri Surabaya, e-mail: atikwintarti@unesa.ac.id
}

\begin{abstract}
Abstrak
Perkembangan teknologi yang semakin pesat seperti smarthphone terutama yang berbasis Android membuat siswa lupa belajar dan lebih memilih game daripada belajar. Salah satu cara untuk mengatasi hal tersebut adalah dengan memanfaatkan smartphone berbasis Android tersebut menjadi media pembelajaran. Penelitian ini bertujuan untuk mengebangkan media pembelajaran berbasis Android pada materi Aritmatika Sosial dan hasil dari pengembangan media pembelajaran ini ditinjau dari kevalidan, kepraktisan, dan keefektifan. Instrumen yang digunakan meliputi lembar validasi media, lembar validasi materi, angket respon siswa, lembar pengamatan, dan skor permainan siswa. Uji coba media pembelajaran ini dilakukan secara terbatas kepada 15 siswa kelas VIII SMP Negeri 1 Wonoayu. Hasil penelitian menunjukkan bahwa media pembelajaran berbasis Android termasuk dalam kategori baik. Media pembelajaran berbasis Android ini memperoleh nilai rata-rata skor total kevalidan 3,59 (ahli media) dan 3,58 (ahli materi) dari skor maksimum 4, sehingga masuk dalam kategori valid. Media pembelajaran berbasis Android ini dikatakan praktis karena berdasarkan persentase angket respon siswa sebesar $83,25 \%$ dan lembar pengamatan sebesar $90,67 \%$. Berdasarkan skor permainan diperoleh $86,67 \%$ siswa memperoleh nilai $\geq 76$ (KKM) sehingga dapat dikatakan bahwa media pembelajaran berbasis Android ini efektif.

Kata Kunci: pengembangan, game Android, media pembelajaran, Aritmatika Sosial.
\end{abstract}

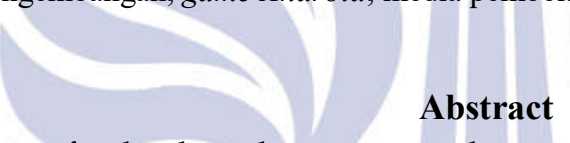

The development of technology that get more advance, such as Android-based smartphones, often makes students prefer to play games than to study. One way to overcome is by utilizing Androidbased smartphone as a learning media. This research develop an Android-based learning media on Financial Mathematic that the result reviewed in terms of validity, practically, and effectiveness. The instruments in this research were media validity sheet, material validity sheet, student questionnaire, observation sheet, and the students' scoresheet. The trial for the learning media were conducted limited to 15 eight graders of SMP Negeri 1 Wonoayu. Based on the research, the average score of total validity was 3,59 (media expert) and 3,58 (material expert) of 4, so that it could be categorized as a valid Android-based learning media. It was practical because the percentage value of student questionnaire was $83,25 \%$ and the average value of the observation sheet was $90,67 \%$. Based on the student's scoresheet, $86,67 \%$ student's score $\geq 76$ (Standar Minimum Score) so that conclud the Android-based learning media was effective.

Keywords: development, Android game, learning media, Financial Mathematic

\section{PENDAHULUAN}

Matematika merupakan mata pelajaran yang telah dipelajari dari tingkat Sekolah Dasar (SD) sampai sekolah menengah (Kemendikbud, 2017). Hiebert and Carpenter (dalam Stylianides, 2007) menyatakan bahwa dalam belajar matematika anak-anak perlu menggunakan pemahamannya. Dalam belajar matematika, diharapkan siswa menggunakan pemahamannya dalam memelajari, memahami dan mengaplikasikan dalam kehidupan sehari- hari. Selain itu, matematika juga merupakan salah satu mata pelajaran yang telah ditetapkan sebagai salah satu mata pelajaran pokok/wajib dalam setiap Ujian Akhir Nasional (UAN) mulai dari jenjang Sekolah Dasar (SD) sampai Sekolah Menengah Atas (SMA) (Kemendikbud, 2017). Selain itu matematika juga mempunyai jam mata pelajaran yang paling banyak (Kemendikbud, 2017). Berdasarkan beberapa hal di atas dapat dikatakan bahwa matematika merupakan salah satu pelajaran yang memiliki peranan penting dalam bidang pendidikan. 
Mettes (dalam Fuadi, 2016) juga mengungkapkan bahwa dalam belajar matematika, siswa hanya mencontoh dan mencatat penyelesaian soal dari guru. Sejalan dengan pendapat Mettes, hasil penelitian Intisari (2017) menyatakan bahwa persepsi siswa mengenai pelajaran matematika ialah pelajaran matematika merupakan mata pelajaran yang memusingkan, menyebalkan, bahkan membuat kepala pusing dan stres. Beberapa hal di atas dapat mengakibatkan pembelajaran matematika membosankan sehingga siswa tidak menyukai pembelajaran matematika dan membuat siswa mengalami banyak kesulitan ketika dihadapkan dengan soal yang berbeda penyelesaian dengan contoh soal.

Pengetahuan mengenai Aritmetika Sosial merupakan materi pokok pada kelas VII SMP semester 2, hal ini tercantum pada lampiran 15 Kemendikbud (2017). Berdasarkan hal tersebut dapat dikatakan bahwa materi Aritmetika Sosial ini merupakan materi yang wajib dipelajari oleh siswa. Namun, Setyono dan Sutarni (2013) mengungkapkan bahwa tingkat kesalahan siswa dalam menyelesaikan masalah matematika pada materi Aritmetika Sosial masih tergolong tinggi, yaitu sebesar $57,84 \%$. Sejalan dengan pendapat Setyono dan Sutarni, Fitriyanti (2018) juga berpendapat bahwa tingkat kesalahan siswa terbesar terletak pada penyelesaian soal dan ketelitian dalam menyelesaikan soal yakni masing-masing sebesar $63,63 \%$ dan $75,75 \%$. Berdasarkan pendapat di atas, dapat dikatakan bahwa masih banyak siswa yang mengalami kesulitan dalam menyelesaikan soal pada materi matematika bab Aritmetika Sosial.

Kesulitan ini pula yang membuat siswa menjadi semakin malas dalam belajar, bahkan saat ini dengan adanya perkembangan teknologi yang semakin pesat seperti smartphone terutama yang berbasis Android membuat siswa lupa akan belajar dan lebih memilih bermain game pada smartphone daripada belajar. Young dan Abreu (2011) mengungkapkan bahwa sebuah studi di Finlandia menyelidiki anak umur 12 - 18 tahun mengalami kecanduan game yang menunjukkan sebanyak 4,7\% anak perempuan serta 5,3\% anak laki-laki. Hal ini dapat menjadi ancaman untuk bidang pendidikan, khususnya dalam pembelajaran matematika, namun hal ini juga merupakan peluang bagi dunia pendidikan jika dapat memanfaatkannya dengan baik yakni dengan membuat media pembelajaran berbasis Android yang valid, efektif, dan praktis.

Berdasarkan latar belakang di atas memungkinkan adanya pengembangan aplikasi game sebagai media pembelajaran berbasis Android pada materi Aritmetika Sosial, diharapkan media ini akan digemari oleh banyak siswa seperti game yang membuat siswa tidak menghabiskan waktu berjam-jam hanya untuk bermain game yang kurang bermanfaat namun ia akan bermain sambil belajar matematika.

\section{Media Pembelajaran}

Media pembelajaran adalah materi instruksional yang disajikan dalam bentuk wahana fisik atau komponen sumber belajar yang dapat merangsang siswa untuk belajar (Arsyad, 2014). Menurut Daryanto (2011) media pembelajaran merupakan sesuatu yang dapat digunakan untuk menyampaikan pesan kepada siswa sehingga dapat merangsang perhatian, minat, pikiran, dan perasaan siswa dalam kegiatan belajar. Sedangkan Mustaji (2016) menyatakan media pembelajaran merupakan sumber belajar berupa sarana fisik yang berisi pesan untuk menyampaikan suatu informasi.

Berdasarkan pengertian-pengertian menurut para ahli mengenai media pembelajaran dapat disimpulkan bahwa media pembelajaran merupakan sarana fisik untuk menyampaikan informasi yang dapat merangsang siswa untuk belajar.

\section{Game Berbasis Android}

Dalam bahasa Indonesia game diartikan sebagai permainan. Menurut Lestari (dalam Pratama, 2014:17) Sebuah permainan adalah sistem dimana pemain terlibat konflik buatan, disini pemain berinteraksi dengan sistem dan konflik dalam permainan merupakan rekayasa atau buatan. Menurut Nazrudin Safaat H (2011) Android adalah sebuah sistem operasi berbasis linux untuk perangkat mobile yang mencakup sistem operasi, middleware, dan aplikasi. Berdasarkan penjelasan-penjelasan di atas dapat di tarik kesimpulan bahwa game berbasis Android adalah permainan yang disajikan pada smartphone Android.

Genre game menurut Sibero (dalam Pratama, 2014) dibagi menjadi beberapa jenis, yakni:

\section{- Action \\ Fighting \\ Shooter \\ Racing \\ Sport \\ - Adventure \\ - Strategi \\ - $\quad$ Role Playing Game (RPG)}

Berdasarkan jenis game di atas penulis mengembangkan game yang bergenre strategi. Game yang dikembangkan penulis berbentuk cerita, yang mana disetiap akhir chapter game siswa harus mengisi kotak kosong yang telah disediakan. Setelah itu, di akhir game akan muncul skor yang diperoleh siswa setelah menyelesaikan game. Game ini melibatkan logika dan kemampuan tentang Aritmatika Sosial dari pemain sehingga game ini termasuk genre game strategi. 


\section{METODE}

Jenis penelitian yang dilakukan yaitu penelitian pengembangan. Penelitian pengembangan yang digunakan mengacu pada model ADDIE, yang terdiri dari 5 tahap yakni (1) Analysis, (2) Design, (3) Development, (4) Implementation, dan (5) Evaluation. Penelitian ini merupakan penelitian pengembangan sebuah game berbasis Android sebagai media pembelajaran pada materi Aritmatika Sosial. Penelitian ini dilaksanakan pada semester ganjil tahun 2019 yang diuji cobakan kepada 15 siswa kelas VIII SMP Negeri 1 Wonoayu.

Produk yang dikembangkan berupa media pembelajaran berbasis Android dengan materi Aritmetika Sosial pada kelas VII yang berbentuk aplikasi dan dapat diinstal pada smartphone berbasis Android. Fitur dalam aplikasi ini terdiri dari kompetensi dasar, materi Aritmatika Sosial, dan permainan. Permainan dalam aplikasi ini berbentuk sebuah cerita, dimana pada setiap akhir chapter siswa harus mengisi kotak kosong yang disediakan.

Instrumen yang digunakan dalam penelitian ini adalah lembar validasi untuk ahli materi dan ahli media, lembar pengamatan, angket respon, dan skor permainan yang akan muncul pada akhir permainan. Adapun teknik analisis kevalidan media pembelajaran yakni dengan cara melakukan rekapitulasi data, menghitung rata-rata skor tiap indikator, menghitung skor tiap aspek, menentukan ratarata skor total, kemudian mengkonversikan hasil tersebut pada kriteria kevalidan media pembelajaran.

Analisis kepraktisan media pembelajaran berbasis Android diperoleh dari angket respon siswa dan lembar pengamatan, media pembelajaran dikatakan praktis apabila media pembelajaran dapat digunakan dengan sedikit revisi atau tanpa revisi serta nilai persentase rata-rata kemampuan pengguna $>50 \%$. Analisis keefektifan media pembelajaran diperoleh dari keberhasilan siswa dalam mencapai tujuan belajar. Siswa dikatakan mencapai tujuan belajar apabila lebih dari $60 \%$ siswa yang menjadi subjek peneitian mendapatkan nilai $\geq 76$ (KKM).

\section{HASIL DAN PEMBAHASAN}

Berikut proses dan hasil pengembangan media pembelajaran berbasis Android:

1. Tahap Analisis

Pada tahap ini dilakukan analisis siswa dan analisis kurikulum. Young dan Abreu (2011) mengungkapkan bahwa $4,7 \%$ anak perempuan dan 5,3\% anak laki-laki umur 12-18 tahun telah kecanduan game. Berdasarkan pernyataan Young dan Abreu dapat dikatakan bahwa anak SMP lebih tertarik untuk bermain game daripada belajar. Kemudian, berdasarkan hasil wawancara dengan guru mata pelajaran didapat bahwa kurangnya media pembelajaran dalam penyampaian materi. Berdasarkan analisis siswa diperoleh kurangnya media pembelajaran dalam penyampaian materi serta siswa lebih tertarik untuk bermain game daripada belajar.

Pada analisis kurikulum, diperoleh bahwa kurikulum yang berlaku di SMP adalah kurikulum 2013. Pada Permendikbud No. 65 tahun 2013, tertulis bahwa prinsip pembelajaran yang saat ini digunakan adalah belajar berbasis aneka sumber belajar, pembelajaran berlangsung dimana saja, serta memanfaatkan teknologi informasi serta komunikasi untuk meningkatkan efisiensi dan efektifitas pembelajaran. Dalam hal ini, media pembelajaran yang memanfaatkan teknologi dan informasi diperlukan dalam pembelajaran untuk meningkatkan efektifitas pembelajaran. Bahrudin dan Wahyuni (2008) menyatakan bahwa untuk menciptakan suasana belajar yang sesuai dengan siswa yakni dengan menyesuaikan media pembelajaran. Kemudian Setyono dan Sutarni (2013) menyatakan bahwa tingkat kesalahan siswa dalam menyelesaikan soal Aritmatika Sosial masih tinggi yakni 57,84\%. Berdasarkan beberapa hal tersebut maka dipilihlah materi yang sesuai untuk media pembelajaran berbasis Android ini adalah materi Aritmatika Sosial.

2. Tahap Desain

Pada tahap ini dilakukan pembuatan RPP, model pembelajaran yang digunakan dalam RPP adalah model pembelajaran langsung dengan menggunakan media pembelajaran berbasis Android setelah siswa mendapatkan materi dari guru pengajar. Kemudian dalam tahap ini juga dilakukan penyusunan flowchart (diagram alir) yang terdiri dari halaman utama, KD, petunjuk, materi, dan permainan. Berikut flowchart media pembelajaran disediakan dalam Gambar 1.
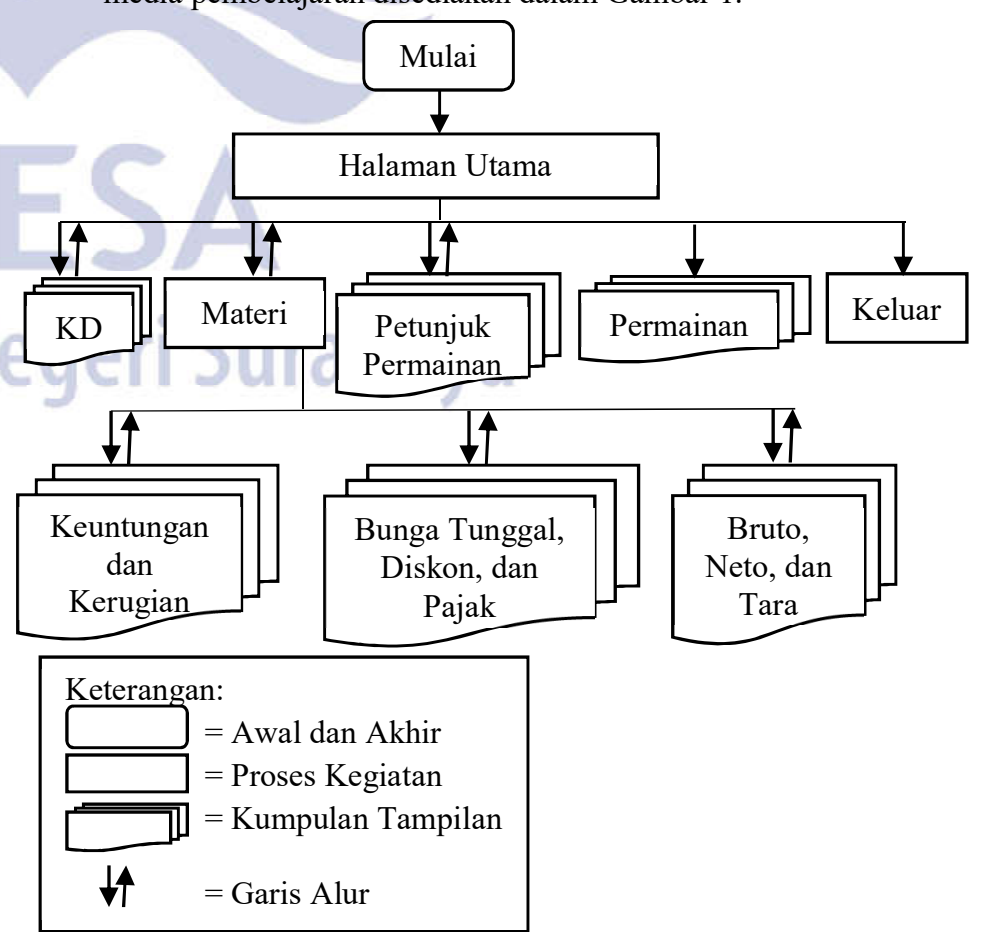

Gambar 1. Flowchart Media Pembelajaran 
Setelah itu, dilakukan perancangan storyboard yang memuat alur media pembelajaran yang berupa gambar teknik dari awal hingga akhir.

3. Tahap Pengembangan

Pada tahap ini dilakukan pengembangan media pembelajaran berdasarkan informasi-informasi yang telah diperoleh sebelumnya. Media pembelajaran didesain sedemikian hingga siswa dan guru mudah untuk menggunakan media pembelajaran tersebut. Sajian materi yang ada dalam media pembelajaran ini yaitu materi Aritmatika Sosial. Media pembelajaran dibuat menggunakan aplikasi Adobe Flash CS6. Media pembelajaran ini memuat permainan yang berhubungan dengan materi Aritmatika Sosial.

Setelah proses pembuatan media selesai, media disimpan dalam bentuk apk yang kemudian apk tersebut ditransfer ke dalam smartphone Android. Selanjutnya aplikasi tersebut diinstall dengan aplikasi pendukungnya yakni Adobe AIR. Setelah semua selesai diinstall media pembelajaran berbasis Android dapat digunakan. Berikut media pembelajaran yang telah dikembangkan.
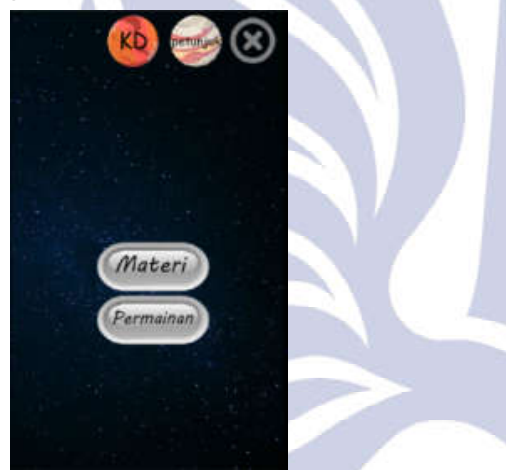

Gambar 2. Halaman Utama Media Pembelajaran

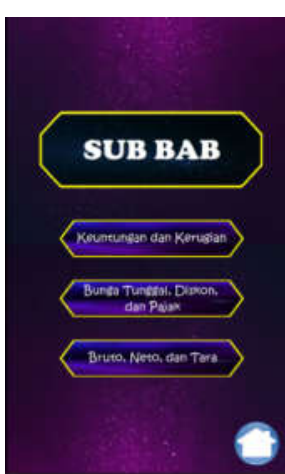

Gambar 3. Materi Media Pembelajaran

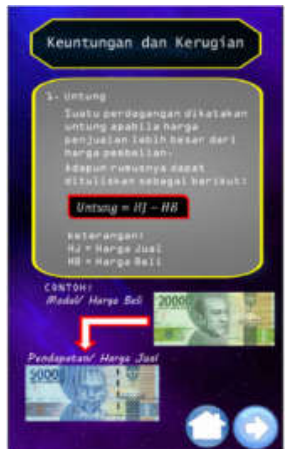

Gambar 4. Sub Materi Keuntungan dan Kerugian

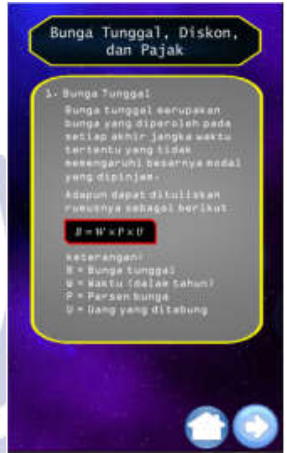

Gambar 5. Sub Materi Bunga Tunggal, Diskon, dan Pajak

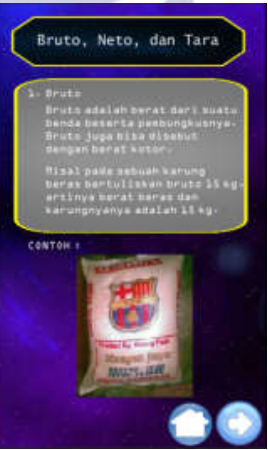

Gambar 6. Sub Materi Bruto, Neto, dan Tara

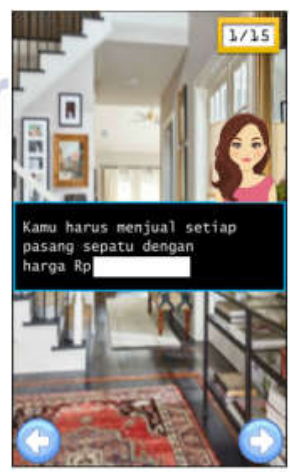

Gambar 7. Permainan 
Media pembelajaran yang telah selesai dikembangkan kemudian divalidasi oleh beberapa validator. Adapun hasil rata-rata total validitas oleh ahli media adalah 3,59 dari 4, dan untuk hasil rata-rata total validitas ahli materi adalah 3,58 dari 4. Berdasarkan kriteria kevalidan media pembelajaran, hasil tersebut masuk dalam kategori valid.

4. Tahap Implementasi

Pada tahap ini dilakukan uji coba media pembelajaran setelah dilakukannya validasi dan revisi berdasarkan komentar dan saran dari validator. Uji coba dilakukan terbatas hanya pada 15 siswa kelas VIII SMP Negeri 1 Wonoayu. Teman peneliti mahasiswa S1 mengamati siswa dalam menggunakan media pembelajaran serta mengisi lembar pengamatan kegiatan penelitian. Lembar pengamatan ini nantinya digunakan sebagai uji kepraktisan media pembelajaran. Setelah bermain game siswa diminta untuk menyetorkan skor yang diperoleh, kemudian hasil tersebut didokumentasi oleh peneliti sebagai bukti.

5. Tahap Evaluasi

Pada tahap ini dilakukan pengevaluasian hasil penilaian kepraktisan yang diperoleh dari hasil angket respon siswa dan hasil penilaian keefektifan yang diperoleh dari skor permainan siswa. Kepraktisan media pembelajaran dapat dinilai dari angket respon siswa dan lembar pengamatan, adapun perolehan persentase rata-rata total angket respon siswa adalah $83,25 \%$, persentase tersebut masuk dalam kategori dapat digunakan tanpa revisi. Kemudian pada persentase lembar pengamatan diperoleh hasil sebesar $90,67 \%$, berdasarkan kriteria kepraktisan persentase tersebut termasuk dalam kategori media pembelajaran baik digunakan oleh siswa. Berdasarkan angket respon siswa dan lembar pengamatan tersebut dapat dikatakan bahwa media pembelajaran berbasis Android ini praktis.

Keefektifan media pembelajaran dinilai dari uji coba terbatas yaitu pada poin perolehan siswa setelah menggunakan permainan pada media pembelajaran. Berikut hasil uji coba terbatas media pembelajaran berbasis Android.

Tabel 1. Hasil Skor Permainan Siswa

\begin{tabular}{|c|c|c|c|}
\hline No. & Subjek & Skor & Ketuntasan \\
\hline 1. & Subjek 1 & 85 & Tuntas \\
\hline 2. & Subjek 2 & 95 & Tuntas \\
\hline 3. & Subjek 3 & 90 & Tuntas \\
\hline 4. & Subjek 4 & 80 & Tuntas \\
\hline 5. & Subjek 5 & 90 & Tuntas \\
\hline 6. & Subjek 6 & 75 & Tidak Tuntas \\
\hline 7. & Subjek 7 & 85 & Tuntas \\
\hline 8. & Subjek 8 & 85 & Tuntas \\
\hline 9. & Subjek 9 & 90 & Tuntas \\
\hline 10. & Subjek 10 & 95 & Tuntas \\
\hline
\end{tabular}

\begin{tabular}{|c|c|c|c|}
\hline No. & Subjek & Skor & Ketuntasan \\
\hline 11. & Subjek 11 & 75 & Tidak Tuntas \\
\hline 12. & Subjek 12 & 80 & Tuntas \\
\hline 13. & Subjek 13 & 85 & Tuntas \\
\hline 14. & Subjek 14 & 85 & Tuntas \\
\hline 15. & Subjek 15 & 85 & Tuntas \\
\hline
\end{tabular}

Berdasarkan Tabel 1 dapat dilihat bahwa 15 subjek uji coba, 13 subjek uji coba memperoleh skor $\geq 76$ (KKM) dan 2 subjek uji coba lainnya mendapatkan $<76$. Artinya, $86,67 \%$ subjek uji coba mencapai tujuan belajar. berdasarkan hal tersebut dapat dikatakan bahwa media pembelajaran ini masuk dalam kategori efeektif.

\section{PENUTUP}

\section{Simpulan}

Penelitian ini telah menghasilkan media pembelajaran berbasis Android pada materi Aritmatika Sosial. Adapun proses pengembangan media pembelajaran ini terdiri dari beberapa tahap yaitu:

a. Tahap Analysis (Analisis), pada tahap ini dilakukan analisis siswa dan analisis kurikulum. Pada analisis siswa diperoleh permasalahan kurangnya media pembelajaran, siswa mengalami kesulitan saat menyelesaikan masalah, dan siswa lebih tertarik untuk bermain game daripada belajar. Pada analisis kurikulum diperoleh Kurikulum yang digunakan siswa SMP adalah kurikulum 2013 dan pada penelitian ini menggunakan materi Aritmatika Sosial. Berdasarkan dua analisis tersebut diperoleh kesimpulan perlunya media pembelajaran berbasis Android pada materi Aritmatika Sosial.

b. Tahap Design (Desain), berdasarkan tahap analisis dilakukan perancangan media pembelajaran yang akan dibuat meliputi pembuatan RPP, yang disusun menggunakan model pembelajaran langsung dengan menggunakan media pembelajaran berbasis Android. Kemudian dilakukan pembuatan flowchart dan storyboard. Berdasarkan desain yang telah dibuat diperoleh hasil sebuah media pembelajaran berbasis Android.

c. Tahap Development (Pengembangan), pada tahap pengembangan dilakukan pengembangan media pembelajaran menggunakan Adobe Flash CS6 sesuai dengan rancangan yang telah dibuat pada tahap desain. Setelah media pembelajaran selesai dibuat, aplikasi ditransfer ke perangkat smartphone dan dilakukan validasi oleh ahli media dan ahli materi. Berdasarkan validasi yang telah dilakukan media pembelajaran telah dikatakan valid oleh ahli media dan ahli materi.

d. Tahap Implementation (Implementasi), setelah dilakukan tahap pengembangan dan media telah dinyatakan valid oleh ahli media dan ahli materi, 
pada tahap implementasi dilakukan uji coba terbatas kepada 15 siswa kelas VIII SMP Negeri 1 Wonoayu.

e. Tahap Evaluation (Evaluasi), pada tahap ini dilakukan evaluasi hasil pengembangan media pembelajaran media pebelajaran berbasis Android berdasarkan kriteria valid, praktis, dan efektif. Berdasarkan penelitian yang telah dilakukan media pembelajaran dinyatakan valid, praktis, dan efektif.

Hasil pengembangan media pembelajaran berbasis Android yaitu sebuah media pembelajaran materi Aritmatika Sosial berbentuk aplikasi yang dapat diinstal pada smartphone berbasis Android. Fitur dalam aplikasi ini adalah KD, Petunjuk, Materi, dan Permainan. Media pembelajaran ini telah memenuhi kriteria valid, praktis, dan efektif. Kriteria pertama yaitu media pembelajaran telah dinyatakan valid oleh ahli media dengan nilai 3,59 dari 4 dan ahli materi dengan nilai 3,58 dari 4. Kriteria yang kedua yakni media pembelajaran dinyatakan praktis dengan persentase angket respon siswa sebesar 83,25\% dan lembar pengamatan sebesar $90,67 \%$. Kriteria yang ketiga yakni media pembelajaran dinyatakan efektif karena $86,67 \%$ siswa mendapatkan nilai $\geq 76$ (KKM).

\section{Saran}

Berdasarkan simpulan di atas, media pembelajaran berbasis Android yang telah dikembangkan telah memenuhi kriteria media pembelajaran yang baik, yakni memenuhi kriteria valid, praktis, dan efektif. Oleh karena itu, saran yang bisa diberikan oleh peneliti adalah media pembelajaran berbasis Android ini dapat digunakan sebagai media pembelajaran bagi siswa kelas VII SMP/MTs. Selain itu, media pembelajaran ini juga dapat dikembangkan lebih baik lagi untuk peneliti selanjutnya.

\section{DAFTAR PUSTAKA}

Huda, Arif Akbarul. 2013. Live Coding! 9 Aplikasi Buatan Sendiri. Yogyakarta: ANDI

Arsyad, Azhar. 2014. Media Pembelajaran. Jakarta: Raja Grafindo Persada.
Daryanto. 2011. Media Pembelajaran. Bandung: Satu Nusa.

Fuadi, Rahmi, dkk.2016.Peningkatkan Kemampuan Pemahaman dan Penalaran Matematis melalui Pendekatan Kontekstual. Jurnal Didaktika Matematika.Vol. 3, No. 1.

Intisari. 2017. Persepsi Siswa Terhadap Pembelajaran Matematika. Jurnal Pendidikan Pascasarjana Magister PAI. Vol 1 (1): hal. 62-71.

Lengkong, Hendra N.,dkk. 2015. "Perancang Penunjuk Rute pada Kendaraan Pribadi Menggunakan Aplikasi Mobile GIS Berbasis Android yang Terintegrasi pada Google Maps". E-journal Teknik Elektro dan Komputer. Vol. 4 (2): hal. 18-25.

Munadi, Y. 2013. Media Pembelajaran. Jakarta: GP Press Group.

Mustaji. $2016 . \quad$ Media Pembelajaran. Surabaya:UNIPRESS

Pratama, Wahyu. 2014. "Game Adventur Misteri Kotak Pandora”. Jurnal Telematika. Vol. 7 (2): hal. 13-31.

Safaat H, Nazruddin 2011. Pemrograman Aplikasi Mobile Smartphone dan Tablet PC Berbasis Android.Informatika. Bandung: Bandung.

Setyono, Dwi dan Sri Sutarni. 2013. Kesalahan Menyelesaikan Soal Matematika dalam Bentuk Cerita Pokok Bahasan Aritmetika Sosial. Makalah disajikan dalam Seminar Nasional Pendidikan Matematika, Surakarta, 15 Mei.

Stylianides, Andreas J. 2007. Learning Mathematics eith Understanding: A Critical Consideration of the Learning Principle in the Principles and Standards for School Mathematics. Vol. 4 (1): hal 103-114.

Tim. 2017. Matematika. Jakarta: Pusat Kurikulum dan Perbukuan, Balitbang, Kemendikbud.

Young, K.S. dan C.N.D. Abreu. 2011. Internet Addiction: A Handbook and Guide to Evaluation and Treatment. Canada: John Wiley \& Sons, Inc. 